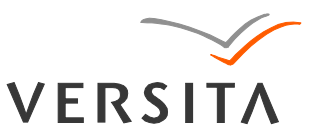

GEOCHRONOMETRIA 40(3) 2013: 187-194

DOI 10.2478/s13386-013-0108-7

VERSIT^

Available online at

www.springerlink.com

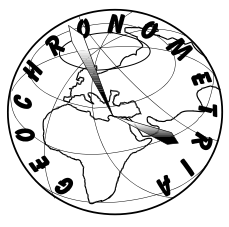

\title{
HOLOCENE SEDIMENTS OF THE USTKA CLIFF (NORTHERN POLAND) IN VIEW OF RADIOMETRIC DATING
}

\author{
RADOSŁAW WRÓBLEWSKI, STANISŁAW FEDOROWICZ and KATARZYNA KAMIEŃSKA \\ University of Gdańsk, Institute of Geography, Department of Quaternary Geomorphology and Geology, \\ Bażyńskiego Street 4, 80-950 Gdańsk, Poland
}

Received 30 September 2012

Accepted 15 March 2013

\begin{abstract}
The cliff in Ustka is an active one. The area is one of the most eroded sea shores of the Polish coast. The Ustka Cliff mainly consists of Holocene sandy deposits, but its basis is built of glacial till and clay. Field search allowed to recognize the structure and sedimentary conditions of Holocene deposits exposed in the cliff. A comparison of dating results obtained for fossil soils and peat as well as aeolian deposits, using ${ }^{14} \mathrm{C}$ and TL methods, respectively, with available literature records is presented. The evaluation of results obtained allowed to define three main dune-forming phases for the first time for this part of the Polish coast. During the research studies new data on the processes and environmental conditions was gained and the development of structure of the area during the last 10 thousand years was reconstructed. The analysis of available data from other sections of the southern Baltic coast shows that results obtained are age similar to those determined for the Leba Spit. The research is part of a project concerning the geomorphology of the Ustka Bay.
\end{abstract}

Keywords: southern Baltic, Ustka Cliff, dunes, fossil soils, TL, ${ }^{14} \mathrm{C}$.

\section{INTRODUCTION}

The cliff in Ustka is an active one. The area is one of the most eroded sea shores of the Polish coast. The ease of access to the Ustka Cliff (Northern Poland; Fig. 1), good testing conditions as well as clearly visible sediments sequences in the cliff in the period from November 2009 to May 2010, allowed conducting the field search. Taking into account that only limited data on the age of the dunes and fossil soils of the southern Baltic coast, particularly in the central coast, is available, the main aim of the study was to examine the structure and sedimentary conditions of Holocene deposits exposed in the cliff, represented mainly by aeolian deposits and separating them fossil soil layers. The data on the age of sediments

Corresponding author: R. Wróblewski

e-mail: dokrw@univ.gda.pl in the cliff, the processes and environmental conditions in which their accumulation took place will enrich the knowledge on Holocene dune-forming phases, their dura-

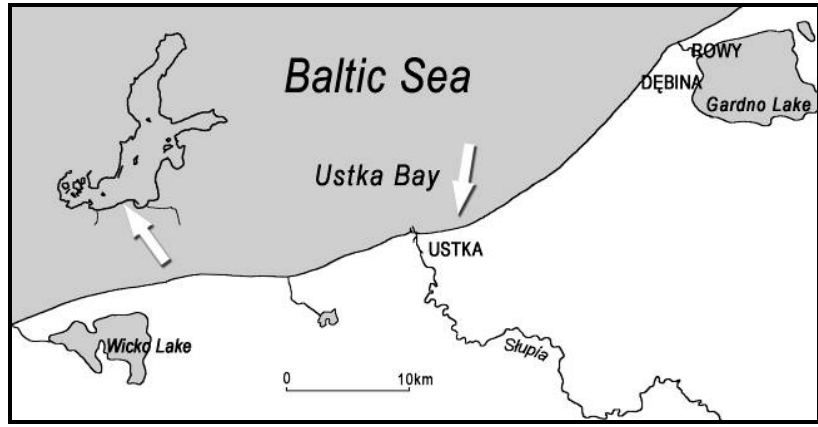

Fig. 1. Location of the study area 
tion and periods separating them. Textual and structural analysis of the aeolian deposits will enable understanding of the conditions of transport and sedimentation as well as identify types of dunes, which deposits formed the Ustka Cliff.

The Ustka Cliff is located to the east of the Ustka fishing port, in the central part of the Ustka Bay. This is part of the cliff shore extending from Ustka to Dębina near Rowy. Extensive research was carried out over a distance between the 229.3 and $232 \mathrm{~km}$ of the Polish coastline (acc. to Maritime Office in Słupsk), i.e. between $2^{\text {nd }}$ and $5^{\text {th }} \mathrm{km}$ from port in Ustka (Fig. 1).

\section{GENERAL CHARACTERISTICS OF THE STUDY AREA}

The Ustka Cliff constitutes part of the Stupsk Plateau, which originated in the zone of glacitectonic deformations related to the ice-sheet advancement older than the Pomeranian Phase (Petelski and Jurys, 1989). It is flat, sometimes undulating area, dissected with the Stupia Valley, mainly composed of glacial tills and clay of an ice-dammed reservoir of the Pomeranian Phase (Petelski and Jurys, 1989). On the northern edge of the plateau, along the coast between Ustka and Poddąbie, there is a belt of dunes overgrown with pine trees. The dunes, predominantly parabolic, are up to several meters high.

The Ustka Cliff mainly consists of sandy deposits, but its basis is built of glacial till and clay. In some sections of the cliff these sediments reach considerable thickness; their roof is lowering towards the west. Both the Pleistocene and Holocene sediments are exposed in the geological profile of the cliff. The Pleistocene deposits are compact, plateau-type and of greater resistance to abrasion. The Holocene is represented by edge dune sands separated by fossil soils. The cliff height increases towards the east - from 3-5 $\mathrm{m}$ in Ustka to $12-15 \mathrm{~m}$ in the vicinity of Orzechowo.

The lowest layer in the profile of the Ustka Cliff is grey glacial till, which contains a clear joint with the predominance of vertical cracks (Marsz and Tobolski, 1993; Florek et al., 1996). Most authors classify this material as lodgement till (Florek et al., 1994). The roof of the till is uneven; it has a maximum height in the vicinity of the $229.7 \mathrm{~km}$, where it reaches the altitude of about $7 \mathrm{~m}$ asl. It is reduced towards the east, and in the vicinity of the $231.3 \mathrm{~km}$ it disappears beneath beach sands.

Directly on the till, without a clear sedimentation boundary, there is a layer of clayey-silty sediment of gray-blue to greenish-blue colour and with variable grain size. The thickness of this sediment ranges from $0.2 \mathrm{~m}$ to $1.8 \mathrm{~m}$; the largest is found between the 228.3 and $230 \mathrm{~km}$. For this series the following TL dates were obtained: $43.5 \pm 6.5 \mathrm{ka}, 45.2 \pm 6.5 \mathrm{ka}$ and $56.5 \pm 7.0 \mathrm{ka}$ (Olszak et al., 2008). In the depressions in the sediment varved structures appear (Marsz and Tobolski, 1993).
On the surface of the clay there lies a peat layer of variable thickness: from $2 \mathrm{~cm}$ to $30 \mathrm{~cm}$ locally. The peat is highly compacted, sanded up and, in places, clayey. It is dated to $11100 \pm 140$ BP (Marsz and Tobolski, 1993), and it originated most likely in the conditions of soggy ground, but without water bodies (Marsz and Tobolski, 1993). In places, in the depressions of the terrain, peat deposits are covered with lacustrine sediments in the form of sandy and clayey calcareous gyttja (Florek et al., 1996).

Beyond land depressions, in the vicinity of limnic sediments, sometimes there is a layer of several dozen $\mathrm{cm}$ of wind-blown sand interbedded by 1 to 5 levels of peat moss.

On the surface of these series of sediments brown fossil soils developed; they were radiocarbon-dated to $2980 \pm 60$ BP (Tomczak, 1993; Florek et al., 1994). It has a well-developed humus horizon and is covered with aeolian sands of varying thickness, in places up to $8.5 \mathrm{~m}$. Amongst the sands there lie younger fossil soils of various ages, dated to $1590 \pm 60 \mathrm{BP}, 1050 \pm 50 \mathrm{BP}$ and 1030 \pm 80 BP (Tomczak, 1993; Florek et al., 1994).

The number of fossil soil layers varies in different parts of the cliff and increases towards the east. Closest to Ustka $(232.5 \mathrm{~km}$ ), where the cliff is low (about $5 \mathrm{~m}$ ) there are two visible fossil soil layers, while at higher levels of the cliff there are more of them. At the highest point of the cliff $(15 \mathrm{~m})$, in the vicinity of the $229.7 \mathrm{~km}$, there are at least five levels of fossil soils. Most soils are poorly developed. Few soil layers, in some sections, developed a clearly visible leaching horizon characteristic of podzolic soils.

\section{MATERIAL AND RESEARCH METHODS}

During field studies, which took place in November 2009 and between 30 April 2010 and 5 September 2010, four places were selected for preparing profiles. The sites were located in the places where the cliff face could be exposed (Fig. 2). The geological structure of the cliff was diagnosed. At each of the sites there were a few exposures made so as they overlapped. The exposures were mapped, indicating the type of deposit, its structures and stratification. This allowed to select the best places for

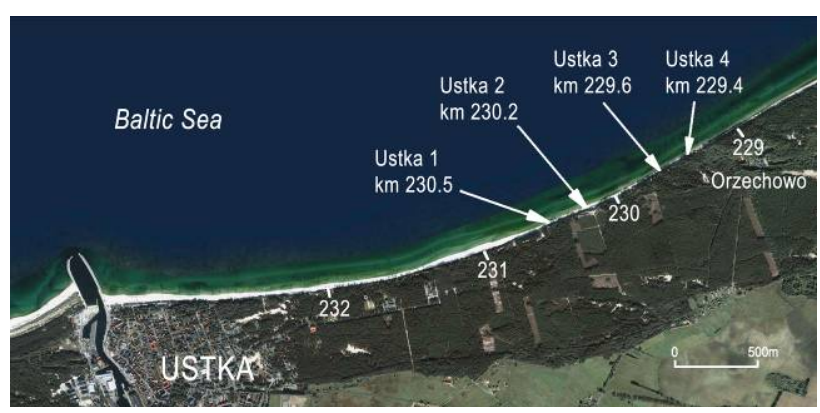

Fig. 2. Location of research sites (source: http://maps.google.com) 
sampling and to obtain details on the cliff structure. All together 22 samples for TL dating, and 3 samples for radiocarbon dating were collected.

Samples of aeolian sands for luminescence dating were collected to metallic pipes of a diameter of $9 \mathrm{~cm}$ and a length of $25 \mathrm{~cm}$. The pipes, whose ends were protected against solar radiation, were driven in the sediment.

Samples for ${ }^{14} \mathrm{C}$ dating were collected from wellpreserved fragments of fossil soils and tree trunks fragments preserved in the sediment at the research site in life position. The TL dating method was chosen for this study due to the fact that aeolian deposits are best research material for this method. In addition, luminescent methods are among the absolute dating methods and their dates can be compared with the calibrated radiocarbon dates.

The deposit moisture was measured in each sample. After drying the dose rate was determined with the use of the MAZAR-2011 gamma spectrometer. The concentrations of ${ }^{226} \mathrm{Ra},{ }^{228} \mathrm{Th},{ }^{40} \mathrm{~K}$ in each sample were obtained from 20 measurements lasting $2000 \mathrm{~s}$ each. The concentrations of radionuclides were converted into dose rates for alpha, beta and gamma radiation, assuming secular equilibria. Adjustments were made for the deposit moisture, dose of cosmic radiation, grain size and time of etching with HF (Aitken and Xie, 1983; Adamiec and Aitken, 1998). The uncertainty of dose rate determination was about 6\% (Poręba and Fedorowicz, 2005).

The equivalent dose (De) was determined after the following pre-treatment. The $80-100 \mu \mathrm{m}$ fraction was separated using a sieve method, treated with $10 \% \mathrm{HCl}$ for about 24 hours, followed by $2 \% \mathrm{NaOH}$ for the same time, and then with $40 \%$ HF for 45 minutes (Bluszcz, 2000). After each treatment the sample was rinsed with distilled water. A sample pre-treated in this way was used to determine the equivalent dose by the TL multiple-aliquot regenerative technique (Wintle and Prószyńska, 1983), according to the description published by Fedorowicz (2006).

After the initial preparation the material was divided into two parts. The first one, left in an unaltered state, was used to measure natural thermoluminescence. The remaining, larger part was optically bleached by the exposure to UV light simulating sunlight for up to 12 hours. For this purpose, the lamp Osram Ultra-Vitalux $300 \mathrm{~W}$ was used. The bleached material was divided into six equal portions. The first one was used to measure the residual thermoluminescence, while the five remaining ones were irradiated with cobalt of the values that would regenerate the previously acquired energy. The measurement of the equivalent dose $(\mathrm{De})$ was performed with the reader/analyser, model RA'94 equipped with a filter BG$28(360-510 \mathrm{~nm})$. Five-milligram weighed samples were heated in argon atmosphere to $400^{\circ} \mathrm{C}$ with the heating rate of $8 \%$. The TL glow curves for heated quartz grains were analysed. Peak heights occurring at $260-300^{\circ} \mathrm{C}$ were measured. Sensitivity of grains was checked by perform- ing complementary measurements according to the technique used in additive technology. In order to determine the equivalent dose the criterion of the light range selection was used. It was a plateau test for the temperature range between $280^{\circ} \mathrm{C}$ and $380^{\circ} \mathrm{C}$ for all samples.

The TL dating of the samples was carried out at the Department of Quaternary Geomorphology and Geology of the University of Gdańsk by S. Fedorowicz (Table 1). The ${ }^{14} \mathrm{C}$ dating of three samples was carried out at the Department of Radioisotopes, the Institute of Physics, the Silesian University of Technology in Gliwice (Table 2).

\section{RESEARCH RESULTS}

\section{Research site Ustka 1}

The research site Ustka 1 is located approximately at the $230.5 \mathrm{~km}$ of the sea shore (Fig. 2). At this point the cliff is around 15 meters high and is dominated by sandy sediments (Fig. 3).

The basis of the profile are Pleistocene sediments up to about $5 \mathrm{~m}$ asl. It is primarily grey glacial till covered by grey-blue clays and silts. These sediments are covered with about $20-\mathrm{cm}$ layer of peat overlain by aeolian deposits, which constitute the main part of the profile. The aeolian deposits are separated by fossil soils of different development level. At this site five levels of fossil soils were diagnosed.

The peat layer is covered with horizontally stratified medium-grained sand, in places interbedded with coarsegrained sand up to $4 \mathrm{~m}$ thick. From this layer, about 0.5 $\mathrm{m}$ above the peat, a sample was taken for the TL dating. The obtained date was $11.4 \pm 1.9 \mathrm{ka}$ (U I/3) (Fig. 3). In

Table 1. $T L$ dating results

\begin{tabular}{|c|c|c|c|c|}
\hline Site & Sample & Lab. No. & Sample description & TL age (ka) \\
\hline \multirow{6}{*}{1} & U I/4 & UG 6406 & aeolian sand & $0.5 \pm 0.2$ \\
\hline & U I/5 & UG 6407 & aeolian sand & $0.5 \pm 0.2$ \\
\hline & U I/6 & UG 6408 & aeolian sand & $0.4 \pm 0.2$ \\
\hline & $U \mathrm{U} / 2$ & UG 6404 & aeolian sand & $1.8 \pm 0.4$ \\
\hline & $\mathrm{U} \mathrm{I/7}$ & UG 6409 & aeolian sand & $0.5 \pm 0.2$ \\
\hline & $\mathrm{UI} / 3$ & UG 6405 & aeolian sand & $11.4 \pm 1.9$ \\
\hline \multirow{12}{*}{2} & $\mathrm{U} \mathrm{IV} / 1$ & UG 6415 & aeolian sand & $0.5 \pm 0.2$ \\
\hline & U IV/2 & UG 6416 & aeolian sand & $1.6 \pm 0.2$ \\
\hline & U IV/3 & UG 6417 & aeolian sand & $1.8 \pm 0.2$ \\
\hline & U IV/4 & UG 6418 & aeolian sand & $1.5 \pm 0.2$ \\
\hline & U IV/5 & UG 6419 & aeolian sand & $1.8 \pm 0.2$ \\
\hline & U IV/6 & UG 6420 & aeolian sand & $1.7 \pm 0.2$ \\
\hline & U IV/7 & UG 6421 & aeolian sand & $1.8 \pm 0.2$ \\
\hline & U IV/8 & UG 6422 & aeolian sand & $2.2 \pm 0.4$ \\
\hline & U IV/9 & UG 6423 & aeolian sand & $5.1 \pm 0.6$ \\
\hline & U IV/10 & UG 6424 & aeolian sand & $5.4 \pm 0.6$ \\
\hline & U IV/11 & UG 6425 & aeolian sand & $5.6 \pm 0.6$ \\
\hline & U III/1 & UG 6412 & aeolian sand & $0.5 \pm 0.2$ \\
\hline \multirow[t]{2}{*}{3} & U III/2 & UG 6413 & aeolian sand & $1.7 \pm 0.2$ \\
\hline & U III/3 & UG 6414 & aeolian sand & $1.9 \pm 0.2$ \\
\hline \multirow{2}{*}{4} & U II/1 & UG 6410 & aeolian sand & $5.0 \pm 0.6$ \\
\hline & $U \| / 2$ & UG 6411 & aeolian sand & $5.6 \pm 0.6$ \\
\hline
\end{tabular}


Table $2 .{ }^{14} \mathrm{C}$ dating results. Dates were calibrated with using IntCal09 calibration curve (Reimer et al., 2009).

\begin{tabular}{|c|c|c|c|c|c|c|}
\hline Site & Sample & Lab. No. & Sample description & ${ }^{14} \mathrm{C}$ age (BP) & $\begin{array}{c}\text { Calibrated Age (range 68\%) } \\
\text { cal BP }\end{array}$ & $\begin{array}{c}\text { Calibrated Age (range 95\%) } \\
\text { cal BP }\end{array}$ \\
\hline 1 & Ust. 02/8 & GdS-1169 & $\begin{array}{l}\text { willow trunk pieces } \\
\text { from layer of peat }\end{array}$ & $2610 \pm 60$ & $\begin{array}{c}2840-2830(1.6 \%) \\
2800-2700(55.7 \%) \\
2640-2610(6.3 \%) \\
2590-2540(4.6 \%)\end{array}$ & $\begin{array}{l}2860-2670(68.8 \%) \\
2650-2490(26.6 \%)\end{array}$ \\
\hline 1 & Ust. 03/8 & GdC-526 & $\begin{array}{l}\text { oak trunk pieces from } \\
\text { layer of peat }\end{array}$ & $2835 \pm 50$ & $3010-2860(68.2 \%)$ & $\begin{array}{c}3140-3120(0.7 \%) \\
3110-3090(0.9 \%) \\
3080-2840(90.9 \%) \\
2830-2790(2.8 \%)\end{array}$ \\
\hline 2 & Ust. 01/4 & GdS-1168 & $\begin{array}{l}\text { wood fragments from } \\
\text { fossil soil }\end{array}$ & $2675 \pm 65$ & $2850-2740(68.2 \%)$ & $\begin{array}{c}2960-2710(94.8 \%) \\
2630-2620(0.6 \%)\end{array}$ \\
\hline
\end{tabular}

this settlement, about 2-2.5 $\mathrm{m}$ above the peat layer, there are probable traces of fossil soil destroyed by drifting. This sediment is covered with a layer of fossil soil located at a depth of about 7 meters, which is composed of two distinct layers (Fig. 4). In depressions this bipartite level of fossil soil turns into the bipartite peat. What is important is that this bipartite soil is also present at the research site Ustka 2. It was also observed at other sites, but it was not recognised at research sites Ustka 3 and 4. In the upper layer of this soil's humus horizon there are fragments of wood and reeds. Under the fossil soil level there are fragments of organic matter in the sand sediment and traces of roots. From this sediment a sample for the TL dating was collected (U I/7) (Fig. 3).

Higher, above the fossil soil level there is sand with fragments of organic matter of the thickness of about $40 \mathrm{~cm}$. Above it there are aeolian deposits of diagonal stratification of the thickness of about $50-70 \mathrm{~cm}$. A sediment sample was collected for the TL dating ( $\mathrm{U} \mathrm{I} / 2)$; the resulting date of this sample was $1.8 \pm 0.4 \mathrm{ka}$. This deposit is covered with the coarse-grained sand layer of horizontal stratification and the thickness of about $20 \mathrm{~cm}$. In this sediment there are interbedded layers of medium- and

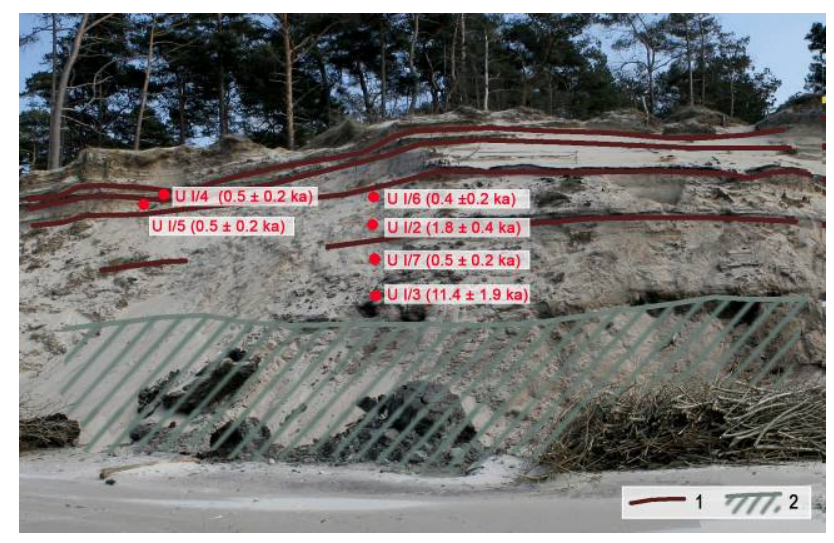

Fig. 3. Location of the TL sampling at the research site Ustka 1 (230.5 km), 1 - main fossil soil levels, 2 - glacial till, May 2010 (Photo R. Wróblewski). fine-grained sand. In addition, disturbances caused by melting snow and ice are found. These structures are made of coarser material of a thickness of several $\mathrm{cm}$. Above there are sands interbedded with thin layers of coarse-grained sand and fragments of organic matter of thickness of about $30 \mathrm{~cm}$. Then, there is a noticeable erosion surface built of coarse-grained windblown material. Next there is a clearly noticeable erosive surface built of coarser blow-out material. From the material lying directly at this border a sample was collected for the $\mathrm{TL}$ dating (U I/5), for which the date of $0.5 \pm 0.2 \mathrm{ka}$ was obtained. Above there is a fossil soil situated at a depth of about 2 meters in relation to the contemporary surface; it contains fragments of reeds and small pieces of charcoal - a trace of the fire. The thickness of this soil is about $20 \mathrm{~cm}$. From underneath yet another sample for the TL dating was collected (U I/6). The dating of this sample indicated $0.4 \pm 0.2 \mathrm{ka}$ BP. Above the soil layer there are horizontally stratified aeolian deposits interbedded with fossil soils at different stages of development. About $30 \mathrm{~cm}$ above there is a fossil soil destroyed by drifting. From between these fossil soil layers the last sample for

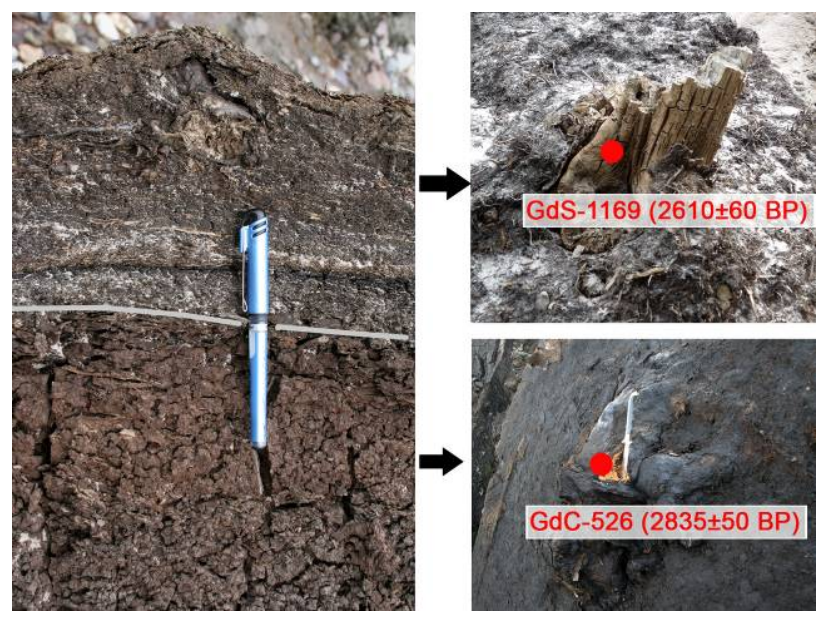

Fig. 4. Location of sampling sites for carbon dating - tree trunks in life position in peat (230.4 km), May 2010 (Photo R. Wróblewski) 
the TL dating was collected ( $\mathrm{U} / 4)$. Its age was estimated at $0.5 \pm 0.2 \mathrm{ka}$. The upper part of the profile is built of contemporary sediments. At a depth of about 1 meter there is a distinct level of a fossil soil. Over it there are aeolian deposits, often interbedded with fragments of organic matter and root traces, which form a typical cliff naspas. At a depth of about $25 \mathrm{~cm}$ traces of a bonfire not older than 40 years were identified.

Approximately 20 meters east of the described research site, on peat layers in the depressions in glacial till, there are very well visible limnic deposits of distinct varve structure. They are covered with about $40-\mathrm{cm}$ thick layer of peat. The peat is clearly bipartite (Fig. 4), and both to the east and west of this site, when moving away from the basin filled with limnic sediment, it turns into a bipartite fossil soil, as described previously in the case of the research site 1 . Its lower layer is peat, which contains oak trunks in the life position and with a diameter of up to several dozen $\mathrm{cm}$ (Fig. 4). This layer is covered with peat with visible fragments of reeds. In this peat there are thinner deciduous tree trunks (with a diameter of several centimetres) in the life position (probably willow) (Fig. 4). At this place, two samples for the ${ }^{14} \mathrm{C}$ dating were collected (Fig. 4). These were pieces of wood: one from an oak trunk, and the second one from the trunk in a higher peat level. The obtained dates were as follows: oak GdC-526, 2835 50 BP (3140-2790 (95.4\%) cal BP), and willow (GdS-1169) 2610 \pm 60 BP (2860-2490 (95.4\%) cal BP) (Table 2, Fig. 4).

\section{Research site Ustka 2}

The second research site is located near the $230.2 \mathrm{~km}$ of the coast (Fig. 2). The cliff at this point is around 10 meters high (Fig. 5).

Pleistocene deposits at this place are up to about $4 \mathrm{~m}$ asl. These are mainly clays and silts, on which there is a $30 \mathrm{~cm}$ thick peat layer. Directly from above this level, from a $60 \mathrm{~cm}$ layer of sand, two samples for the TL da-

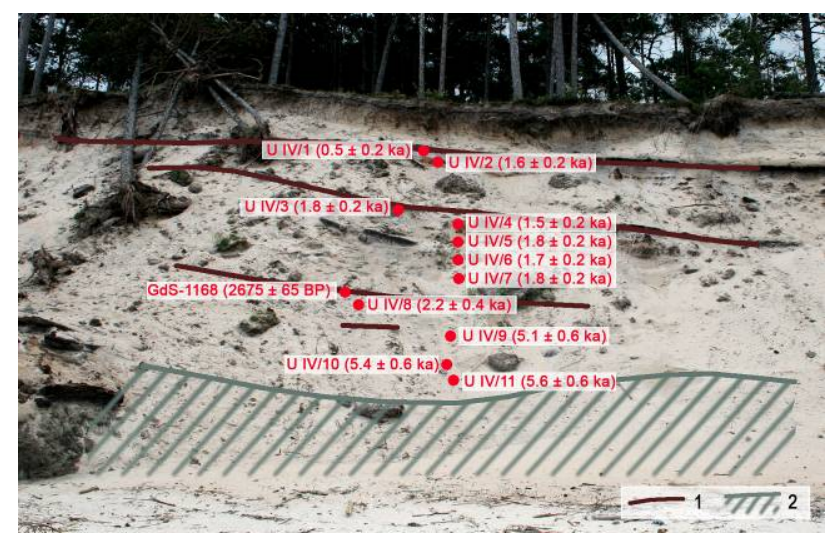

Fig. 5. Location of sampling sites for the TL dating at the research site Ustka 2 (230.2 km), 1 - main fossil soil levels, 2 - glacial till, September 2010 (Photo R. Wróblewski) ting were collected (U IV/11, IV/10 U). Their age was, respectively, $5.6 \pm 0.6 \mathrm{ka}$ and $5.4 \pm 0.6 \mathrm{ka}$ (Fig. 5). Above the sands there are traces of drifted soil previously existing in this place. A sediment sample was collected directly from below the layer of the fossil drifted soil (U IV/9), the age of which was $5.1 \pm 0.6 \mathrm{ka}$. Above there are three distinct levels of fossil soils. The soil located the lowest in the profile, at a depth of about $4.5 \mathrm{~m}$ below the present ground level, has a well-developed $25 \mathrm{~cm}$ humus horizon. In the soil wood fragments were found, one of which was subjected to ${ }^{14} \mathrm{C}$ dating (sample GdS-1168). The result of this test was $2675 \pm 65$ BP BP (2960-2710 (94.8\%), 2630$2620(0.6 \%)$ cal BP) (Table 2). From just below this soil a sample was collected for the TL dating (U IV/8), the age of which was determined at $2.2 \pm 0.4$ ka (Table 1). Above the well-developed fossil soil there are finegrained aeolian sands with horizontal stratification, in places disturbed by snow and ice melting and slope processes. In the upper part of the sediment there are root traces and frequent interbeds of sand with organic matter. From these sediments four samples for the TL dating were collected (U IV/7, U IV/6, U IV/5 and U IV/4). Their age was, respectively, $1.8 \pm 0.2 \mathrm{ka}, 1.7 \pm 0.2 \mathrm{ka}$, $1.8 \pm 0.2 \mathrm{ka}$ and $1.5 \pm 0.2 \mathrm{ka}$. Over these sediments, at a depth of about $2 \mathrm{~m}$, there is another layer of fossil soil. It is significantly destroyed by drifting. There are traces of leaching (Ees) and illuviation (Bhfe) horizons. Directly under it, in the leaching horizon (Ees) a sample U IV/3 was collected; its age was determined at $1.8 \pm 0.2 \mathrm{ka}$. Above there is ferruginous sand which is part of the soil profile (Bhfe) of yet another fossil soil. The last distinct fossil soil level is about one meter below the present ground level. This soil is well developed; the humus horizon is about $15 \mathrm{~cm}$ thick. There are distinctive leaching (Ees) and illuviation (Bhfe) horizons. From the leaching horizon the TL date of $0.5 \pm 0.1 \mathrm{ka}$ was obtained, while from the illuvial horizon - of 1.6 $\pm 0.2 \mathrm{ka}$ (Fig. 5).

\section{Research site Ustka 3}

The research site Ustka 3 is located approximately at the $229.6 \mathrm{~km}$ of sea shore (Fig. 2). The height of the cliff is significant and amounts to some 14 meters (Fig. 6).

At this site Pleistocene sediments reach high up to about $7 \mathrm{~m}$ asl. They are mainly grey glacial tills. On it there are grey-blue clay and silt deposits about $50 \mathrm{~cm}$ thick which are covered with a peat layer of variable thickness of about $35 \mathrm{~cm}$. Admixture of fine-grained sand and dust are found in the peat. Above there is finegrained aeolian sand of horizontal stratification, sometimes disturbed, forming a bed about $6 \mathrm{~m}$ thick. At a depth of about $3.5 \mathrm{~m}$ from the modern ground surface, there is a distinct layer of fine-grained strongly ferruginous sand stratified horizontally. From below this level, from a series of aeolian fine-grained sands, 2 samples were collected for the TL dating (U III/3, U III/2) (Fig. 6). These samples were dated, respectively, at $1.9 \pm 0.2 \mathrm{ka}$ and $1.7 \pm 0.2 \mathrm{ka}$. 


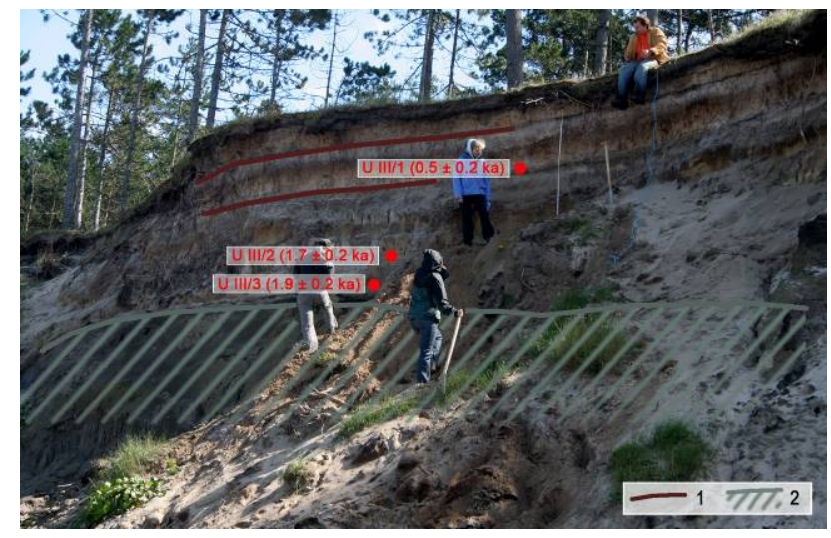

Fig. 6. Location of sampling for the $T L$ dating at the research site Ustka 3 (229.6 km), 1 - main fossil soil levels, 2 - glacial till, September 2010 (Photo R. Wróblewski)

In the upper series of sands, above strongly ferruginous layer, there are two levels of fossil soils. The top one is at a depth of about $0.5 \mathrm{~m}$ below the current ground level, while the bottom one of about $1.8 \mathrm{~m}$. The lower level of fossil soil is destroyed by drifting. Both fossil soil levels have the features of a well-developed podzol soil. There are distinct leaching (Ees) and illuviation (Bhfe) horizons. In the illuvial horizons there is a large amount of iron compounds. A sample for the TL dating (U III/1) was collected at a depth of $1.5 \mathrm{~m}$ between two levels of fossil soils. The result of this dating was $0.5 \pm 0.2$ ka (Fig. 6).

\section{Research site Ustka 4}

The research site Ustka 4 is located approximately at the $229.4 \mathrm{~km}$ of the sea shore (Fig. 2). The height of the cliff at this point is about $10 \mathrm{~m}$. The Pleistocene deposits reach about $6 \mathrm{~m}$ asl here.

In the lower part of the profile there are Pleistocene sediments: grey glacial till, merging into grey-blue clay and silt. This deposit is covered with a peat layer of thickness of about $30 \mathrm{~cm}$. The peat is covered with finegrained sand interbedded with coarse-grained sand, of about $50 \mathrm{~cm}$ thickness. From this sediment, above the peat, a sample was taken for TL dating (U II/2). Its age was determined to be $5.6 \pm 0.6 \mathrm{ka}$ (Fig. 7). On the finegrained sands there is sand with a large amount of iron compounds forming a very compact layer difficult to analyze. The thickness of this sediment reaches almost $3 \mathrm{~m}$. At some locations coarser sand layers of the nature of deflation pavement are visible. The border between the ferruginous sands and the sands lying above without enrichment in iron compounds is strongly disturbed. The disturbances resemble convolute lamination. There are also visible root traces. In the upper sands there are noticeable traces of snow melting. About $1 \mathrm{~m}$ below the modern surface a sample for the TL dating was collected (U II/1), which gave the date of $5.0 \pm 0.6$ ka (Fig. 7).

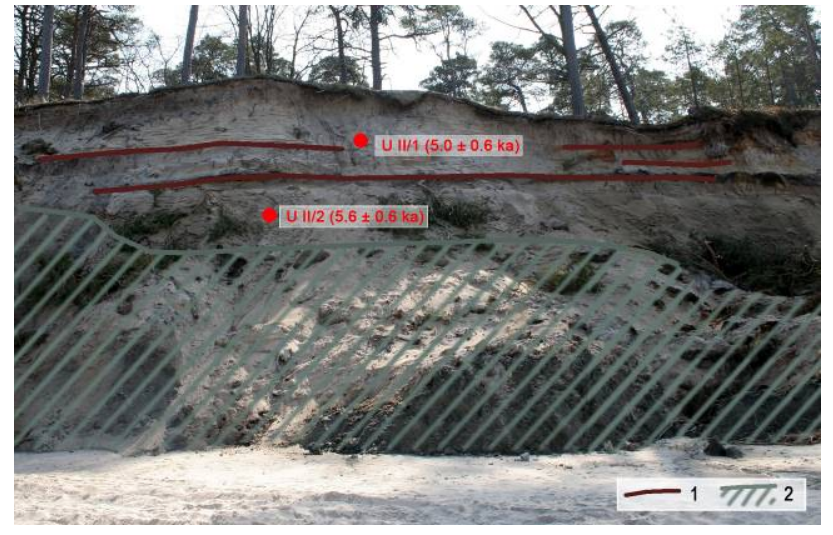

Fig. 7. Location of sampling for the $T L$ dating at the research site Ustka 4 (229.4 km), 1 - main fossil soil levels, 2 - glacial till, September 2010 (Photo R. Wróblewski)

Above, up to the surface, there is a $50-70-\mathrm{cm}$ layer of fine-grained sand with interbeds of organic matter resembling cliff naspas.

\section{DISCUSSION AND CONCLUSIONS}

The base of the entire length of the cliff is built of lodgement and flow till. Directly on the till there is a layer of grey-blue clay and silt. The genesis of this deposit is not fully understood. Most likely, this layer was formed in water-filled depressions between the clayey hills, in which accumulation of solifluction and wash material from the elevated parts of the area took place (Marsz and Tobolski, 1993). Directly on the clay layer, on the wet, muddy ground peat accumulation took place. This peat was radiocarbon-dated at $11100 \pm 140$ BP (13260-12670 (95.4\%) cal BP) (about $230 \mathrm{~km}$ ) (Marsz and Tobolski, 1993) and 10230 \pm 110 BP (12450-11400 (95.4\%) cal BP) about $229.7 \mathrm{~km}$ ) (Tomczak, 1993). On the peat dwarf birch and willow encroached (Marsz and Tobolski, 1993). In some research sites, in depressions, directly on the peat deposits there are limnic sediments (site Ustka 1). They take the form of sanded and clayed calcareous gyttja with varve structures ( $c f$. Florek et al., 1996). Directly on the peat the first, relatively low aeolian forms developed, built of fine-grained sands interbedded with moss peat. They were TL dated to $11.4 \pm 1.9 \mathrm{ka}$. The aeolian sand accumulation did not take place continuously and the sand did not cover the entire area with a compact layer. This was also not the material associated with the development of the coastal zone. At that time the coastline was at least a few dozen km north, gradually moving south. About 9300 yrs ago (Miotk-Szpiganowicz et al., 2009) it was a dozen $\mathrm{km}$ north of the analysed area. During this time, the Słupsk Bank was already an island and the sea level was lower than the current by more than $20 \mathrm{~m}$ (Miotk-Szpiganowicz et al., 2009).

It is possible that between $11.4 \pm 1.9$ and $5.6 \pm 0.6 \mathrm{ka}$ no great changes in the landscape of the area occurred. There 
are neither well developed soil levels, the age of which would fall in this range, nor erosive levels. This issue, however, requires further study. Probably at that time there constantly existed depressions or a larger reservoir (lake) with a varied coastline in which limnic sediments were deposited. At least from $5.6 \pm 0.6 \mathrm{ka}$ in the area adjacent to the reservoir numerous aeolian forms were developing. As a result of natural processes associated with the development of the reservoir or by lowering the water level, the overgrowing process of the reservoir with peat started. On top of the limnic deposits (research site 1) there is a thick, $40-\mathrm{cm}$ layer of distinctly bipartite peat. Oak forest marched onto the peat bog $(2835 \pm 50 \mathrm{BP})$. In the vicinity aeolian processes were inhibited; under the oak forest a soil level, dated by Tomczak (1993) to $2980 \pm 60$ BP $(229.7 \mathrm{~km})$, was developing. It has a welldeveloped accumulation horizon. This fossil soil is also located on the research sites Ustka 1 and 2. At the site 1 $(230.5 \mathrm{~km})$ it is composed of two layers of humus horizon (A), separated by a thin layer of sand. At site 2 $(230.2 \mathrm{~km})$ it is very well developed and has a large thickness (about $30 \mathrm{~cm}$ ). Fragments of wood found there were subjected to the ${ }^{14} \mathrm{C}$ dating. The resulting date was GdS-1168, 2675 \pm 65 BP (2960-2710 (94.8\%), 2630-2620 $(0.6 \%)$ cal BP).

A large thickness of the peat and a relatively large diameter of oak trunks may indicate a long time of occurrence of such plant communities in this place. Oak forests in this period (3000-2000 BP) also occurred in other parts of the southern Baltic coast. They are best recognised on the Gardno-Łeba Lowland where rapid conversion of oak to beech stands, probably caused by fire (Tobolski, 2001), was also recorded.

It should be noted that the outcrop of peat with preserved oak trunks was discovered only at this short fragment of the cliff, both in research conducted in 20092010, as well as during observations of other authors. Preliminary analysis of an oak trunk in life position in the peat suggests that this forest could have burnt. Subsequent changes in water conditions could have resulted in higher groundwater table, which meant that the area was at least periodically flooded with water and peat began to accumulate again, this time built of reed. On such substrate willow trees entered, relatively quickly to be covered with aeolian material. This peat layer was discovered along a longer fragment of the cliff.

The bipartite peat is covered with fine-grained aeolian sands from older forms, which were subjected to very short transportation. Their age in many places was not reset, hence the TL dates from about $5.0 \mathrm{ka}$ and younger. It can be concluded, thus, that the peat was first buried under aeolian sand drifted from older forms (inland dunes) in the area, later also covered with sand probably transported from the already existing dunes located at seashore of the southern Baltic Sea, which at that time was just a few km north. The intensity of aeolian processes, which took place about $6000-5000$ years ago, can be related to a Littorina transgression as well as forest fire probably initiated by human. Archaeological and palaeoecological data indicate that Southern Baltic coast was certainly inhabited at that time. Human influence was well marked. The first pollen of Cerealia appear $c a$. 5500 BP (Latałowa 1992, Ralska-Jasiewiczowa and Latałowa 1996).

Transgression associated with intensive abrasion of the coast activated massive amounts of rock material in the coastal process. Large part of this material used to build up beaches and dynamically developing dune forms in their hinterland, which could have emerged in the area reaching far inland. The shoreline was moving south. The next dune-forming phases in the analysed area are associated with a typical coast development and transportation of the material from the nearby emerging dune forms on the low cliff and spit forms located to the west of the analysed section of the coast. The material from these types of forms, rich in sand, is also currently windblown onto the Słupsk Plateau. The dune-forming process did not last forever. Layers of aeolian sand are interbedded with fossil soil levels. Their number varies in different parts of the cliff. The largest number of fossil soil layers occurs at the research sites Ustka $1(230.5 \mathrm{~km})$ and 2 $(230.2 \mathrm{~km})$, while lowest in the research site 4 $(229.4 \mathrm{~km})$. Some of these levels are poorly developed or were destroyed by drifting. Sand is often interbedded with thin layers of organic matter.

Aeolian relief of this area was undergoing constant change. Between dunes there were local depressions, often waterlogged, as evidenced by preservation of fragments of reeds and peat in some fossil soil levels. There were often changes in groundwater levels. In the examined aeolian sediments horizontal stratification prevailed. Only in places diagonal layering was noticeable. This may indicate fairly fast moving dune forms at positive balance of deposits. The structure of aeolian sediments contains few erosive borders. These forms resemble dune fields, entering the mature forms.

\section{Dune-forming phases}

In the analysed fragment of the Ustka Cliff, on the basis of the conducted TL and ${ }^{14} \mathrm{C}$ dating, the presence of deposits of at least three dune-forming phases was revealed. They were compared with the dune-forming phases of the Łeba Spit as determined by Borówka (2001) (Fig. 8).

The first aeolian forms developed around $11.4 \pm 1.9 \mathrm{ka}$. The next dune-forming phase in the Ustka Cliff is represented by aeolian sands dated to about $5.6 \pm 0.6 \mathrm{ka}$ and $5.0 \pm 0.6 \mathrm{ka}$. On the Leba Spit the first phase ended around $3340 \pm 130$ BP (Fig. 8), while phase 2 lasted from about 3300 to 2500 BP (Borówka, 2001).

In the aeolian sediments of the research site Ustka 2 (similarly to the site 1) traces of fossil soil destroyed by drifting were identified. The soil was dated between 


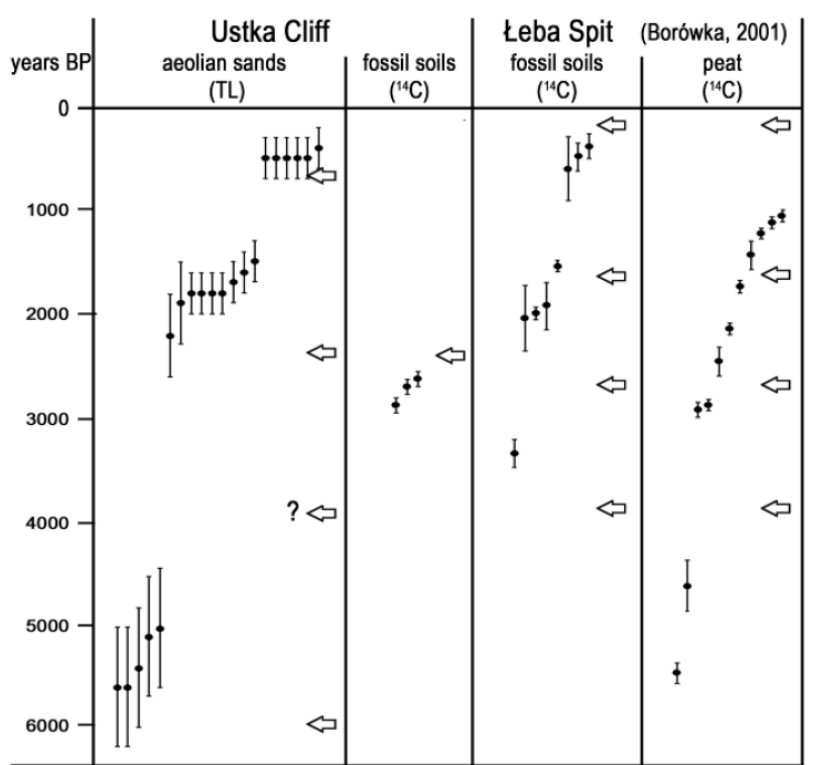

Fig. 8. Dune-forming phases identified on the Łeba Spit and in the Ustka Cliff.

$5.1 \pm 0.6 \mathrm{ka}(\mathrm{U} \mathrm{IV} / 9)$ and $2.2 \pm 0.4 \mathrm{ka}(\mathrm{U} \mathrm{IV} / 8)$. It may be a remnant of the soil level aged around $3 \mathrm{ka}$.

The next level of aeolian deposits are sands at the age from $1.9 \pm 0.2 \mathrm{ka}(\mathrm{U} \mathrm{III} / 3)$ to $1.5 \pm 0.2 \mathrm{ka}(\mathrm{U} \mathrm{IV} / 4)$ (Table 1). This phase corresponds to the phase 3 diagnosed on the Łeba Spit and having a duration from $2.5 \mathrm{ka}$ to $1.5 \mathrm{ka}$. (Borówka, 2001). The most recent series of aeolian sediments is represented by the sands of the age of about $0.5 \mathrm{ka}$ and younger (Table 1). This date coincides with the beginning of aeolian processes on the Leba Spit, which have continued to date.

In the highest parts of the profiles of the Ustka Cliff there are fossil soil levels of insignificant thickness. Mostly these are sediments typical of cliff naspas, which result from the earlier processes.

\section{REFERENCES}

Adamiec G and Aitken MJ, 1998. Dose rate conversion factors update. Ancient TL 16: 37-50.

Aitken MJ and Xie J, 1983. Moisture correction for annual gamma dose. Ancient TL 8: 6-9.

Bluszcz A, 2000. Luminescence dating of quaternary sediments - theory, limitations, interpretation problems. Geochronometria 17: 104 (in Polish).

Borówka R, 2001. Historia rozwoju wydm na Mierzei Łebskiej (The development history of the dunes on Leba Barrier). In: Przemiany Środowiska geograficznego nizin nadmorskich południowego Bałtyku w vistulianie i holocenie, (ed. K. Rotnicki), Bogucki Wydawnictwo Naukowe, Poznań: 81-84 (in Polish).

Fedorowicz S, 2006. Methodological aspects of luminescence dating of Central Europe's neopleistocene deposits. Wydawnictwo Uniwersytetu Gdańskiego 157 (in Polish).
Florek E, Florek W and Orłowski A, 1996. Budowa geologiczna $i$ ewolucja strefy brzegowej w okolicy Ustki (Geological structure and evolution of the coastal zone near Ustka). In: 45 Zjazd Polskiego Towarzystwa Geograficznego, Słupsk-Ustka 18-21 września 1996. Przewodnik wycieczek, Słupsk: 47-52 (in Polish).

Florek W, Marsz A, Orłowski A, Tobolski K and Tomczak A, 1994. Stanowisko Ustka. Budowa Geologiczna i wiek osadów budujacych odcinak klifowy Ustka-Rowy (Ustka research site. Geology and age of the deposits building cliff Ustka-Rowy). In: 2 konferencja Geologia i geomorfologia Pobrzeża i południowego Bałtyku, Słupsk: $73-76$ (in Polish).

Latałowa M, 1992. Man and Vegetation in the Pollen Diagrams from Wolin Island (NW Poland). Acta Paleobotanica 32(1): 123-249.

Marsz A and Tobolski K, 1993. Osady późnoglacjalne i holoceńskie w klifie między Ustka a ujściem potoku Orzechowskiego (Late Glacial and Holocene deposits in the cliff between Ustka and Potok Orzechowski mouth). In: Geologia i geomorfologia Pobrzeża i południowego Bałtyku, (ed. W. Florek), Wydawnictwo Pomorskiej Akademii Pedagogicznej w Słupsku, Słupsk: 201-250 (in Polish).

Miotk-Szpiganowicz G, Uścinowicz S, Przezdziecki P and Jegliński W, 2009. Reconstruction of the paleo-landscapes of the southern Baltic. In:, MACHU (Managing Cultural Heritage Underwater), Final Report No 33., (eds. M. Manders, R. Oosting, W. Brouwers), Educom Publisher BV, Rotterdam: 80-84.

Olszak I, Florek W, Seul C and Mojewski M, 2008. Stratygrafia i litologia mineralnych osadów wystepujących w klifach środkowej części polskiego wybrzeża Bałtyku (Stratigraphy and lithology of minerogenic deposits in coastal cliffs, middle section of the Polish Baltic coast). Landform Analysis 7: 113-118 (in Polish).

Petelski K and Jurys L, 1989. Geneza północnej krawędzi Wysoczyzny Słupskiej między Wrzoścem a Główczycami (Genesis of the northern edge of the Slupsk Plateau between Wrzosiec and Glowczyce). Studia i materiaty oceanologiczne 56: 251-255 (in Polish).

Poręba G and Fedorowicz S, 2005. Gamma spectrometry for OSL and TL dating of loess deposits at Dybawka and Tarnawce (SE Poland). Geochronometria 24: 27-32.

Ralska-Jasiewiczowa M and Latałowa M, 1996. Poland. In: Palaeoecological Events During the Last 15000 Years: Regional Syntheses of Palaeoecological Studies of Lakes and Mires in Europe, (ed. B.E. Berglund, H.J.B. Birks, M. Ralska-Jasiewiczowa and H.E. Wright), John Wiley \& Sons Ltd: 403-472.

Reimer PJ, Baillie MGL, Bard E, Bayliss A, Beck JW, Blackwell PG, Bronk Ramsey C, Buck CE, Burr G, Edwards RL, Friedrich M, Grootes PM, Guilderson TP, Hajdas I, Heaton TJ, Hogg AG, Hughen KA, Kraiser KF, Kromer B, McCormac FG, Manning S, Reimer RW, Richards DA, Southon,JR, Talamo S, Turney CSM, van der Plicht $\mathrm{J}$ and Weyhenmeyer CE, 2009. IntCal09 and Marine09 radiocarbon age calibration curves, $0-50,000$ years cal BP. Radiocarbon 51: 1111-50.

Tobolski K, 2001. Wybrana problematyka fitogeograficzna, paleoekologiczna i paleopedologiczna Niziny Gardnieńsko-Lebskiej (Selected phytogeographical, paleoecological and paleopedologiczna issues of Gardno-Leba Plain). In: Przemiany środowiska geograficznego nizin nadmorskich poludniowego Battyku $w$ vistulianie $i$ holocenie (Transformation of the geographical environment of coastal lowlands of the Southern Baltic in Vistulian and Holocene), (ed. K. Rotnicki), Bogucki Wydawnictwo Naukowe, Poznań: 31 -52 (in Polish).

Tomczak A, 1993. Datowanie metoda ${ }^{14} \mathrm{C}$ wychodnie utworów organicznych na brzegu morskim między rowami a jeziorem Kopań (The ${ }^{14} \mathrm{C}$ age of the organic deposit in outcrops at Baltic coast between Rowy and Kopan Lake). In: Geologia i geomorfologia Pobrzeża i południowego Bałtyku. (ed. W. Florek), Wydawnictwo Pomorskiej Akademii Pedagogicznej w Słupsku, Słupsk: 187-199 (in Polish)

Wintle AG and Prószyńska H, 1983. TL dating of loess in Germany and Poland. PACT 9: 547-554.

Google Corp., Maps, http://maps.google.com 